\title{
DÜNYADA VE TÜRKIYE'DE YAŞANAN OLAYLARIN TURIZME YANSIMALARI: 1960'TAN GÜNÜMÜZE TARİHSEL BİR DEĞERLENDİRME
}

\author{
Sebahattin Emre DILEK ${ }^{1}$ \\ Nur KULAKOĞLU DILEKK
}

Atrf/(O: Dilek, Sebahattin Emre ve Dilek, Nur Kulakoğlu (2017). Dünyada ve Türkiye'de Yaşanan Olayların Turizme Yansimalar: 1960'tan Günümüze Tarihsel Bir Değerlendirme. Hitit Üniversitesi Sosyal Bilimler Enstitüsü Dergisi, Yıl 10, Sayı 2, Aralık 2017, ss.1083-1108

Özet: Turizm sektörünün boyutsal, yeniliksel, niteliksel ve hızl gelişimi beraberinde sektörü olumlu ve olumsuz etkileyen olayların değerlendirilmesi gerekliliğini de ortaya çıkarmaktadır. Bu amaç doğrultusunda çalışmada, 1960 yılından günümüze kadar olan süreçte Dünyada ve Türkiye'de yaşanan ekonomik, sosyal, siyasal ve çevresel olaylarin turizm sektörüne yansimalar ve olumlu/olumsuz etkileri yıllar bazında tarihsel araştırma yöntemi kullanılarak değerlendirilmiştir. Veriler ise doküman analizi tekniği kullanılarak derlenmiştir. Bu doğrultuda, tarihsel olaylan gün, ay, yıl bazında arşivlemiş olan bir web sitesinden 1960 - 2017 yıllar arası dikkate alınarak elde edilen ve ulaşılan 991 doküman analiz edilmiştir. Araştırma sonucu turizmle doğrudan ilgili 144 olayın sektöre olan olumlu ve olumsuz etkileri belirlenerek, gelecekte turizmi etkileyebilecek olayların yorumsamacı yaklaşım ile bir değerlendirmesi yapılmıştır.

Anahtar Kelimeler: Tarihsel Yöntem, Türkiye Turizmi, Dünya Turizmi

\footnotetext{
Makale Geliş Tarihi: 28.09.2017/ Makale Kabul Tarihi: 13.11.2017

1 Yrd. Doç. Dr., Batman Üniversitesi, Turizm İşletmeciliği ve Otelcilik Yüksekokulu, e-posta: s.emre.d@hotmail.com

2 Arş. Gör., Batman Üniversitesi, Turizm İşletmeciliği ve Otelcilik Yüksekokulu, e-posta: nurkulakoglu@hotmail.com
} 


\section{Reflections of The Events In The World and Turkey On Tourism: A Historical Evaluation from 1960 to Present}

Citation/C: Dilek, Sebahattin Emre ve Dilek, Nur Kulakoğlu (2017). Reflections of The Events In The World and Turkey On Tourism: A Historical Evaluation from 1960 to Present, Hitit University Journal of Social Sciences Institute, Year 10, Issue 2, December 2017, pp. 1083-1108

Abstract: The dimensional, innovative, qualitative and rapid development of the tourism sector also reveals the necessity of evaluating the events which affects the tourism sector positively and negatively in the historical process. For this purpose, the reflection of the economic, social, political and environmental events in Turkey and the world during the period from 1960 to the present to the tourism sector as a positive and negative effects have been evaluated by using historical method. In the scope of historical research method, document review technique was used as data collection technique. Accordingly, a total of 991 documents from a web site, which has archived historical events by day, month, and year were analyzed by taking into consideration the years 1960 to 2017. The positive and negative effects of the 144 events, that were determined directly related to tourism. The events that may affect the tourism sector in the future were evaluated with an interpretive approach.

Keywords: Historical Method, Tourism in Turkey, World Tourism

\section{GIRIŞ}

Turizm sosyal, ekonomik, çevresel ve siyasal olaylar gibi iç ve diş etkenlere karşı oldukça hassas bir sektördür. Bu yapısından dolayı; savaş, terör, çevresel ve ekonomik kriz gibi olaylardan en hızlı ve fazla etkilenen sektörlerin başında gelmektedir (Hacıoğlu ve Saylan, 2014).

Dünya Turizm Örgütü'nün (UNWTO) verilerine göre; son 60 y1lda turizm, dünyanın en büyük ve en hızlı büyüyen ekonomik sektörlerinden biri haline gelmek için sürekli büyümesini sürdürmüştür. Dünya genelinde uluslararası turist varışları 1980 yılında 278 milyon, 2000 yılında 674 milyon iken 2016 yılında turizme katılanların sayıs1 1 milyar 235 milyona ve uluslararas1 turizm gelirleri de 1 trilyon 220 milyar dolara ulaşmıştır (UNWTO, 2017). Dünyada turizmin yıllar içerisindeki gelişimine bakıldığında (1960’tan günümüze), söz konusu rakamların birtakım kriz durumları dışında (ekonomik, psikolojik, doğal, siyasi, sosyal vb.) genel olarak artma eğiliminde olduğu görülmektedir. Dünya Turizm Örgütü'nün 2030 projeksiyonuna göre de, önümüzdeki yıllarda söz konusu eğilimin artacağı öngörülmektedir (UNWTO, 2017). 
Her toplumsal olay gibi turizm de tarih içinde bazen yavaş bazen hızlı olmak üzere, fakat sürekli olarak gelişme göstermiştir (Olalı, 1963). Görülen bu gelişimin başlıca özellikleri aşağıdaki gibi özetlenebilir (Olalı ve Timur, 1988:44):

- $\quad$ Boyutsal gelişme: Turistik tüketici sayıları ve turizm harcamaları gibi turizmin hacim yönünden artışına işaret etmektedir.

- Hızlı gelişme: Turizmin gelişiminin diğer toplumsal olayların gelişimine göre daha hızlı olmasını ifade etmektedir.

- Yenilik: Özellikle teknolojik gelişmelere bağlı olarak turizmin de gelişim göstermesini açıklamaktadır. Uzun menzilli uçuşlar ve bilgisayarlı rezervasyon sistemleri bu yeniliklere örnek olarak gösterilebilir.

- $\quad$ Niteliksel gelişme: Turizmin hem arz hem de talep boyutunda uluslararası hatta kıtalararası bir özellik kazanmış olduğunu belirtmektedir.

Olalı ve Timur'un ifade etmiş olduğu özellikler, turizmin yıllar bazında değerlendirilmesinde son derece önemlidir. Nitekim dünyada yaşanan olaylar ve bunların turizme etkisi oldukça fazladır. Ekonomik krizler, savaşlar, doğal afetler, hastalıklar ve salgınlar, teknolojik gelişmeler gibi birçok olumlu ya da olumsuz değişken turizmin gelişiminde önemli rol oynamaktadır.

Bu çalışmada da 1960'lardan günümüze kadar Türkiye ve dünyada yaşanan ekonomik, sosyal, siyasal ve çevresel olayların turizm sektörüne ilişkin yansımaları ve etkileri yıllar bazında tarihsel yöntem kullanılarak değerlendirilmiştir. Araştırma sonucu turizmle doğrudan ilgili 144 olayın sektöre olan olumlu ve olumsuz etkileri belirlenerek, gelecekte turizmi etkileyebilecek olayların yorumsal bir değerlendirmesi yapılmıştır.

\section{YÖNTEM}

Nicel araştırmalarda kullanılsa da, daha çok nitel araştırmalarda tercih edilen yöntemlerden biri olan tarihsel yöntem kullanılarak gerçekleştirilen bu çalışmada, 1960'l1 yıllardan günümüze dünyada ve Türkiye'de yaşanan olaylar ve bu olayların turizm sektörüne olan yansımaları yıllar bazında ele alınmıştır.

Araştırmada tarihsel yöntemin kullanılmasındaki amaç ise, geçmişte turizm sektörünü olumlu ya da olumsuz etkileyen olayların günümüz ile ilişkisini kurarak bir sentez yapmak ve turizm sektörünü gelecekte etkileyebilecek olayların bir izdüşümünü sunabilmektir. Nitekim tarihsel araştırma yöntemi, 
geçmişteki olayların zaman ve yer gösterilerek ve birbirleri ile nedensel ilişkilerinin belirlenerek o olaylara ilişkin anlatı kurulması yöntemi şeklinde ifade edilmektedir (Bowen, 2009; Berg, 2012). Doküman analizi; nitel veri toplama aracı olarak, gözlem ve görüşmenin dişında araştırılması hedeflenen olgu ya da olgular hakkında bilgi içeren materyallerin incelenmesi ve analizi şeklinde ifade edilmektedir (Yıldırım ve Şimşek 2008: 187). Doküman analizine konu olan kaynaklar; arşiv verileri ve tarihsel veriler (Baş ve Akturan, 2008) olabileceği gibi; film, video ve fotoğraflar ile (Yildırım ve Şimşek 2008) internet kaynakları da (Baş ve Akturan, 2008) doküman analizleri kapsaminda yararlanılan kaynaklardandır.

Bu bağlamda, tarihsel olayları gün, ay, yıl bazında arşivlemiş olan ve 2008 yllindan itibaren hizmet vermeye başlayan tarihte bugün adlı web sitesinden (www.tarihtebugun.org) ulaş1lan dokümanlar 1960- 2017 yıllar1 aras1 dikkate alınarak analiz edilmiştir. Bu web sitesinin seçilmesindeki temel kriterler, 1,5 senelik uzun bir kodlama ile oluşturulmuş veri tabanına sahip olması, araştırma - doğrulama çalışması yaparak objektif ve ücretsiz bir veri platformu sağlaması ve 1300 yılından itibaren tüm olayları kronolojik bir şekilde ayrıştırarak sunması şeklinde özetlenebilir. Öyle ki Walcott (1994), olayların belirli bir kronolojik düzen içerisinde ve dolaysız bir şekilde aktarımının yapılmasının nitel araştırma süreçlerinde güvenirliğin sağlanması noktasındaki önemine vurgu yapmaktadır. Ayrıca söz konusu web sitesinin çeşitli bilimsel çalışmalarda da (Açıkalın ve Kılıç, 2017; Kırıc1, 2017) veri kaynağ1 olarak kullanılması sitenin seçilme sürecinde etkili olmuştur.

Söz konusu web sitesinden elde edilen veriler, Miles ve Huberman (1984) tarafından önerilen birbirini takip eden üç aşamalı bir sınıflandırma içerisinde incelenmiştir. Bu aşamalardan ilkini gözlem, görüşme veya doküman incelemesi gibi çeşitli tekniklerle toplanan "verilerin azaltılması" (data reduction) aşaması oluşturmaktadır ve bu doğrultuda araştırmanın amacına uygun olarak turizm sektörüne etki etmediği düşünülen olaylar araştırma dışında bırakılmıştır. Veri analizinin ikinci kısmını ise "verilerin görsel hale getirilmesi" süreci oluşturmaktadır. Bu kapsamda, veri azaltılması sürecinde ayıklanan, özetlenen ve dönüştürülen veriler Miles ve Huberman'ın da belirttiği şekilde (1984) yıllar bazında tablolaştırılmıştır. Bunun temel gerekçesi ise "geştalt psikolojisi yaklaşımı"ndan hareketle insan zihninin uyaranları bir bütün olarak algılama eğiliminde olmasıdır (Solso, 1991; Koffka, 1999; Bowen, 2005). Miles ve Huberman (1984) 
tarafından önerilen veri analiz sürecinin son basamağı ise "sonuca ulaşma ve teyit etme"dir. Bu bağlamda toplanmış olunan verilerden hareketle ve tümevarımcı bir yöntemle bir sonuca ulaşmaya çalış1lmıştır. Sonuca ulaşmaya çalışırken ortaya çıkan araştırmanın güvenirliği sorunsalı ise birbirinden bağımsız üç akademisyen görüşlerinin Miles ve Huberman'ın (1994) önerdiği güvenirlik formülü (Güvenirlik = Görüş Birliği/ (Görüş Birliği + Görüş Ayrılığ1 x 100) ile gerçekleştirilmiştir.

Bu kapsamda üç akademisyenden, doküman inceleme tekniği ile elde edilen toplam 991 olayın turizme olumlu ya da olumsuz etki edip etmediğine göre incelenmesi istenmiş ve formülden hareketle güvenirlik (144/144+18x100) 0,88 olarak hesaplanmıştır. Doğrudan turizme olan olumlu ya da olumsuz etkisi belirlenen 144 olay kronolojik olarak yirmişer yıllık periyodlar halinde 1960-1979, 1980-1999 ve 2000-2017 olmak üzere üç dönem altında tablolaştırılmıştır. Bunun temel nedeni ise 1960, 1980 ve 2000 yıllarının ekonomik, siyasi ve sosyal açılardan turizmde olumlu ya da olumsuz anlamda iz birakan tarihler olmasıdır.

\section{ARAŞTIRMANIN KISITLILIKLARI}

Araştırma, tek web sitesi üzerinden açık erişimi olan ulusal ve uluslararası gazetelerden elde edilen veriler ele alınarak gerçekleştirilmiş olup, veri çeşitlemesine (triangulation) gidilememiştir. Bunun temel nedenini ise zaman ve maliyet değişkenleri oluşturmaktadır. Ayrıca araştırmacıların konuyu ele alış biçimi doğrudan turizme etki eden olumlu ve olumsuz olayları kapsamaktadır. Bu nedenle dolaylı olarak turizme etki eden unsurlar çalışmada dikkate alınmamıştır.

Araştırmanın bir başka kısıtı ise elde edilen verilerin 1960 ile 2017 yılları ile sinırlı tutulmasıdir. Turizmi etkileyen olaylar kapsaminda 1960'tan sonrasının incelemeye alınmasının temel nedeni, öncelikle Birinci Dünya Savaşı ve ardından 1929 Büyük Buhranı ve İkinci Dünya Savaşı’nın yaratmış olduğu ekonomik, siyasal ve toplumsal sorunlar nedeniyle sanayileşme çalışmalarının 1960'lı yıllarda başlayabilmesi ve dünyadaki turizm hareketliliğinin de bu dönemden sonra artış göstermesidir (Büyükşalvarcı vd., 2016). Türkiye'de de 1923-1950 yılları arasında siyasal konjonktürün dengesiz durumu, savaş ortamı ve ekonomik sorunlardan dolayı turizmi geliştirmek adına gerekli çalışmalar başlatılamamıştır. 1960 
y1lına kadar turizme gereken önem verilemese de, bu tarihten itibaren devlet politikası haline getirilen Beş Yıllık Kalkınma Planları ile gerekli önlemler alınmaya başlamıştır (Birinci Beş Yıllık Kalkınma Planı, 1963-1967). Bununla birlikte, Dünya Turizm Örgütü’nün verileri 1960 y1lından öncesini ayrıntılı bir şekilde kapsamadığından dolayı, web sitesi üzerinden elde edilen verilerin turizmi olumlu ya da olumsuz anlamda etkileyip etkilemediği anlamlı bir şekilde değerlendirilememektedir. 
Dünyada ve Türkiyede Yaşanan Olayların Turizme Yansımaları: 1960’tan Günümüze Tarihsel Bir Değerlendirme

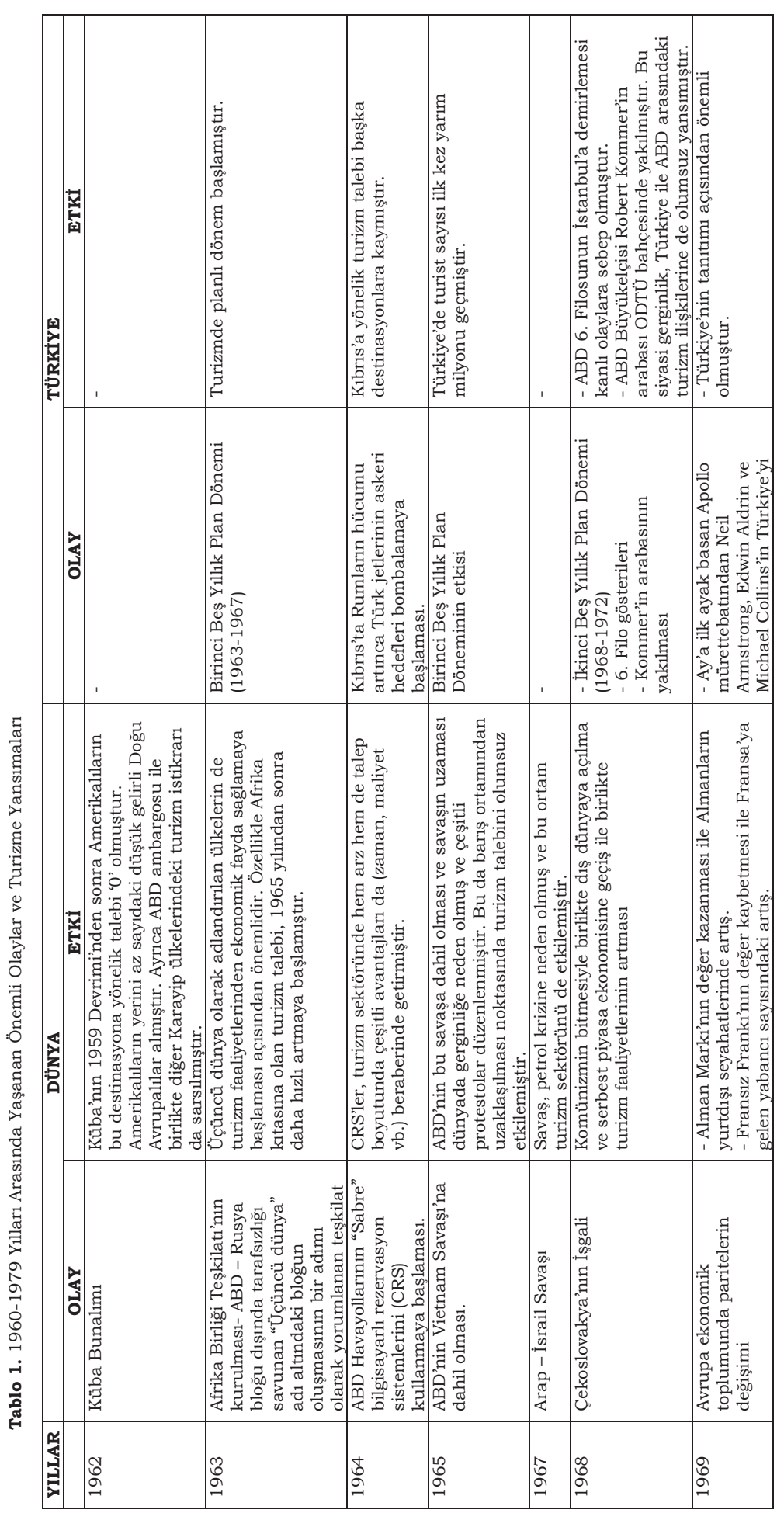

Hitit Üniversitesi Sosyal Bilimler Enstitüsü Dergisi - Yıl 10, Sayı 2, Aralık 2017 | 1089 


\begin{tabular}{|c|c|c|c|c|c|c|}
\hline & 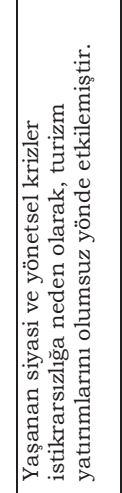 & 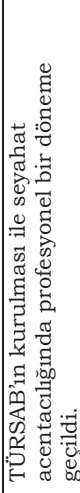 & 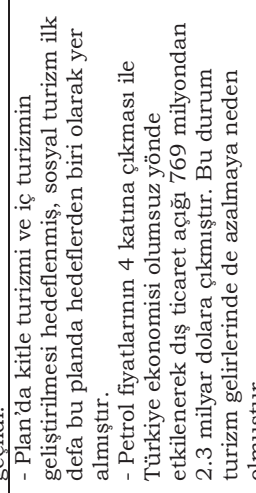 & 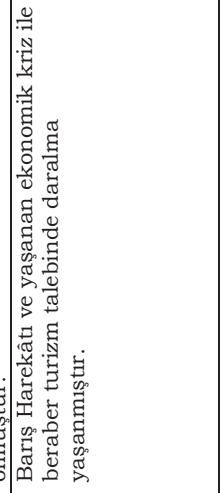 & 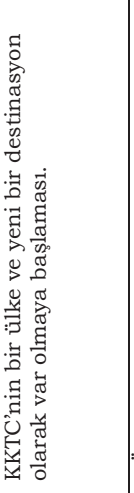 & 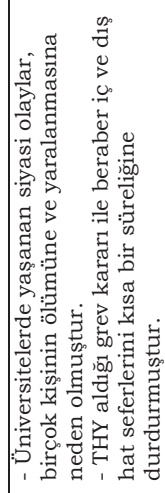 \\
\hline & 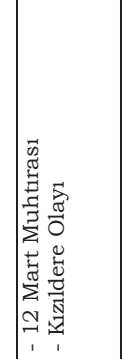 & 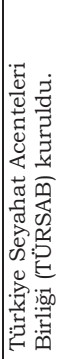 & 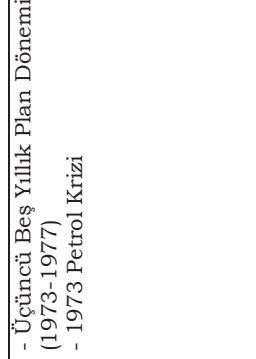 & 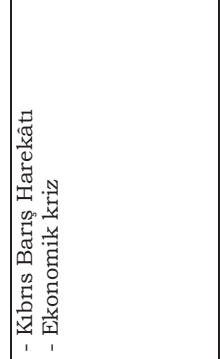 & 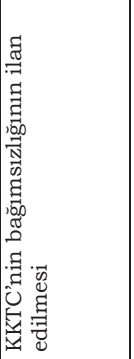 & 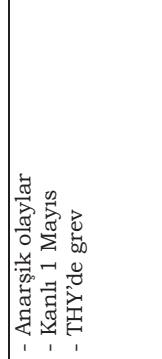 \\
\hline & 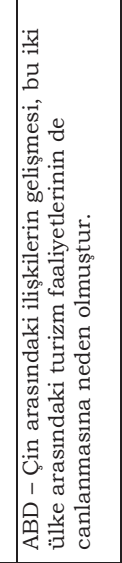 & & 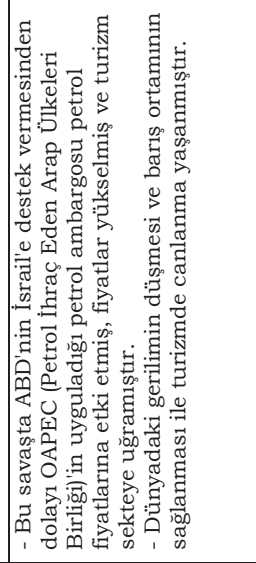 & 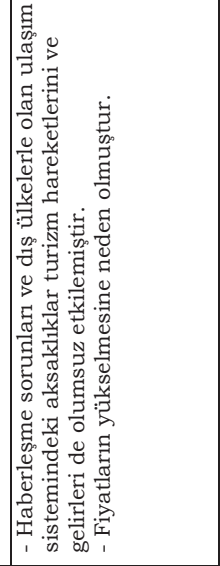 & 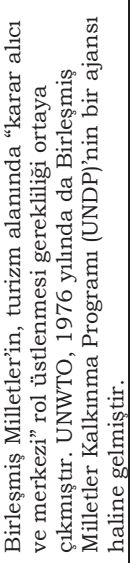 & \\
\hline & 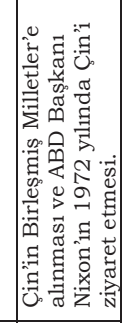 & & 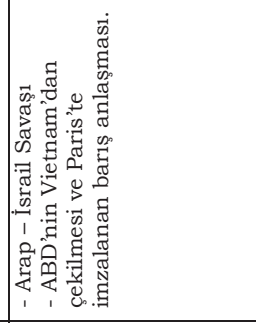 & 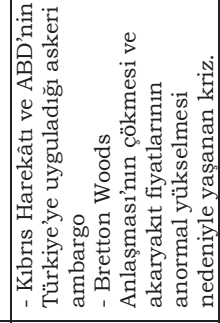 & 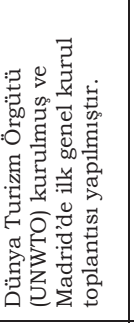 & \\
\hline & ̂ㅡㅁ & $\begin{array}{l}\mathbb{N} \\
\text { Oे } \\
-\end{array}$ & $\begin{array}{l}0 \\
\hat{N} \\
\end{array}$ & 裉 & & 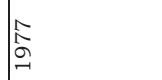 \\
\hline
\end{tabular}

1090 | Hitit Üniversitesi Sosyal Bilimler Enstitüsü Dergisi - Yıl 10, Sayı 2, Aralık 2017 
Dünyada ve Türkiyede Yașanan Olayların Turizme Yansımaları: 1960’tan Günümüze Tarihsel Bir Değerlendirme

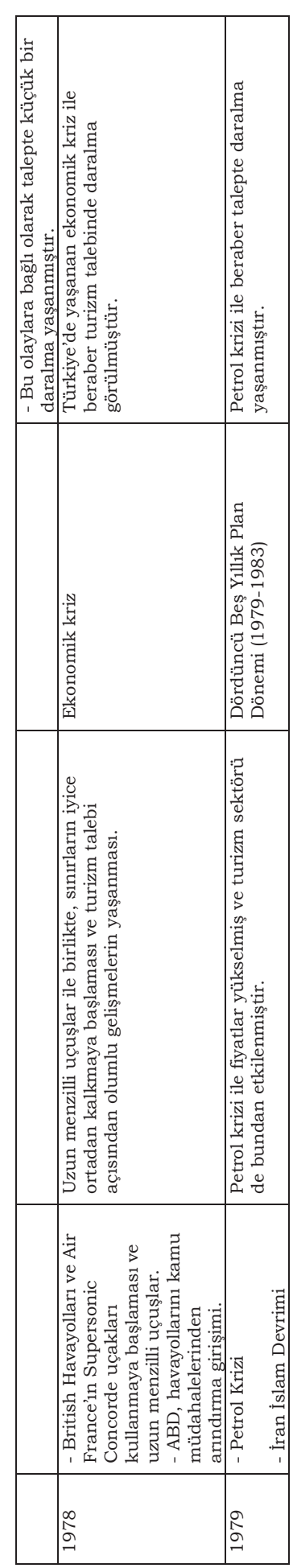

Hitit Üniversitesi Sosyal Bilimler Enstitüsü Dergisi - Yıl 10, Sayı 2, Aralık 2017| 1091 


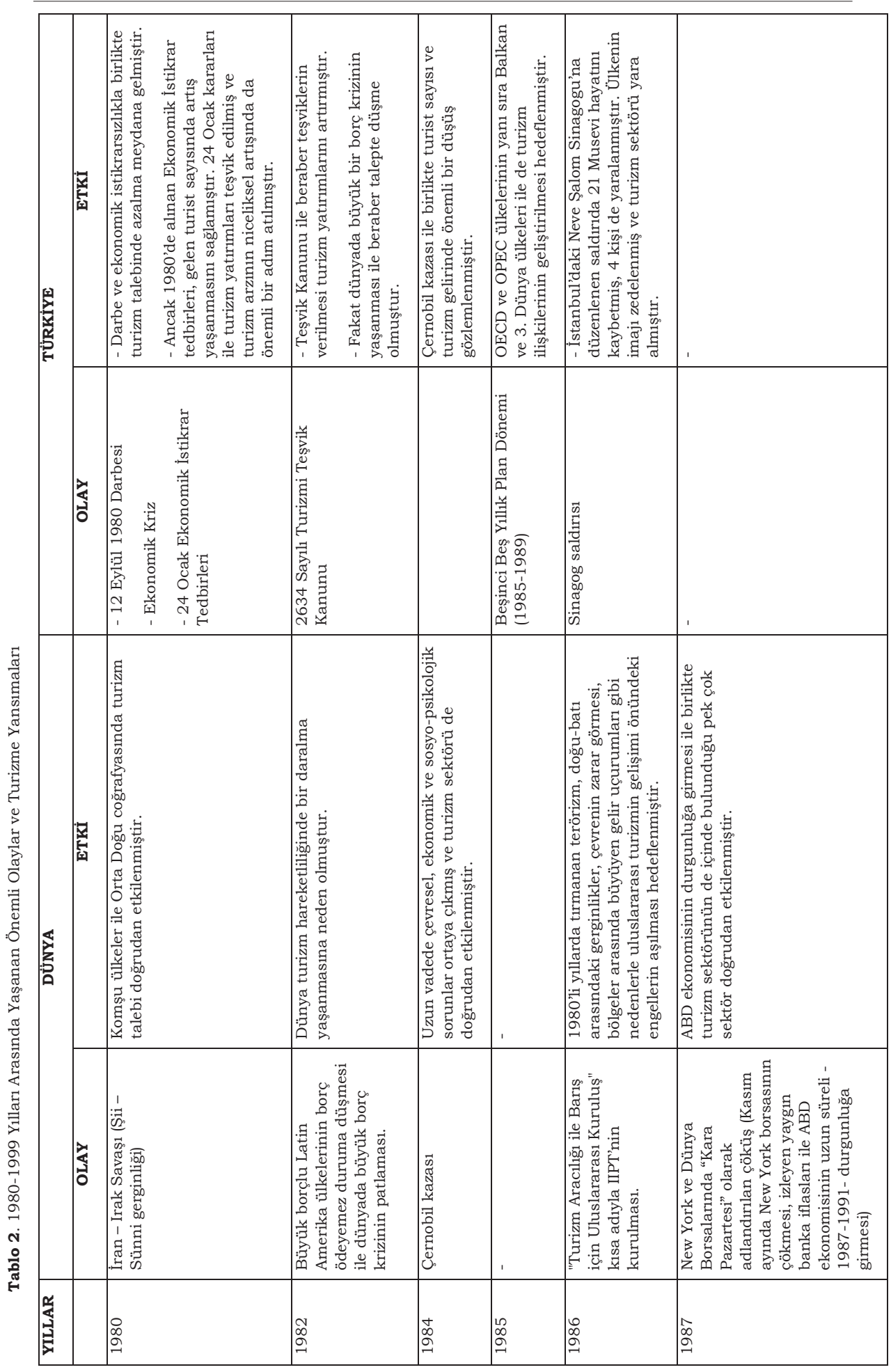

1092 | Hitit Üniversitesi Sosyal Bilimler Enstitüsü Dergisi - Yıl 10, Sayı 2, Aralık 2017 
Dünyada ve Türkiyede Yaşanan Olayların Turizme Yansımaları: 1960’tan Günümüze Tarihsel Bir Değerlendirme

\begin{tabular}{|c|c|c|c|c|c|}
\hline 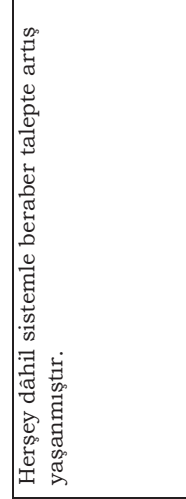 & 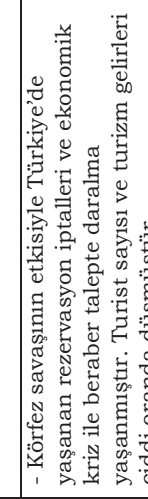 & & 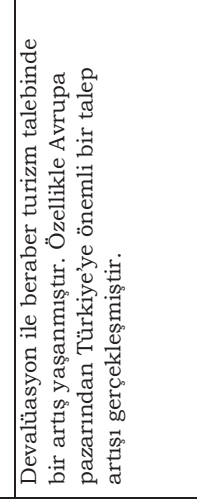 & 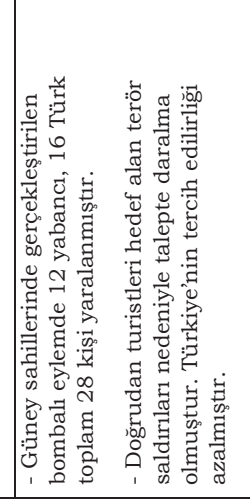 & 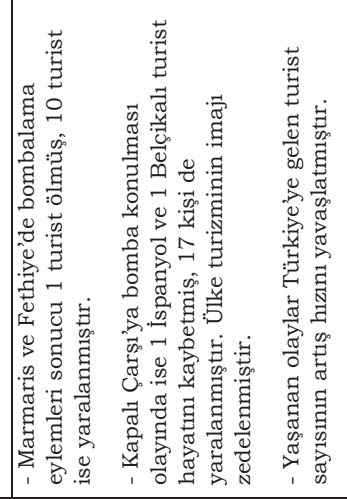 \\
\hline 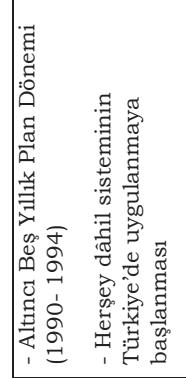 & 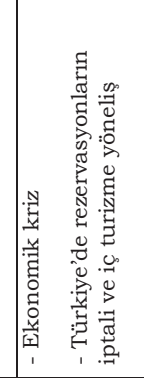 & & 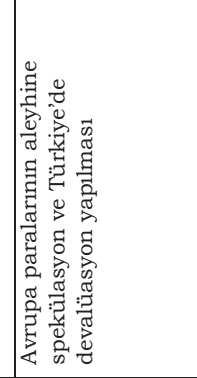 & 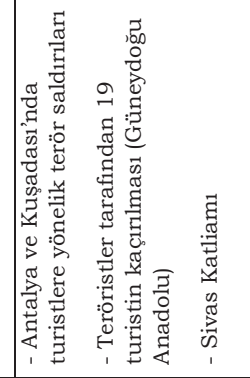 & 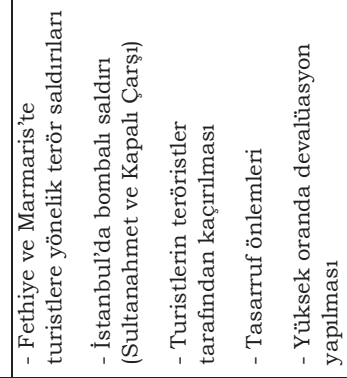 \\
\hline 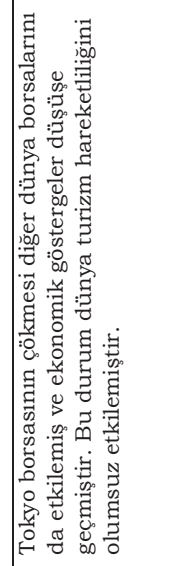 & 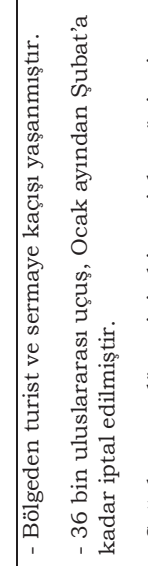 & 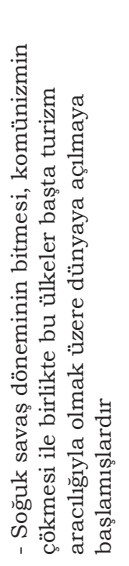 & 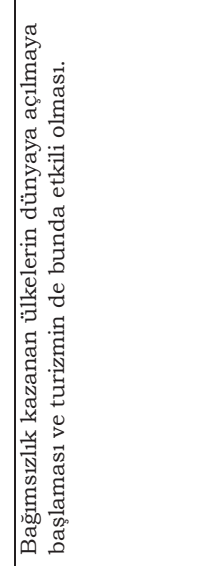 & 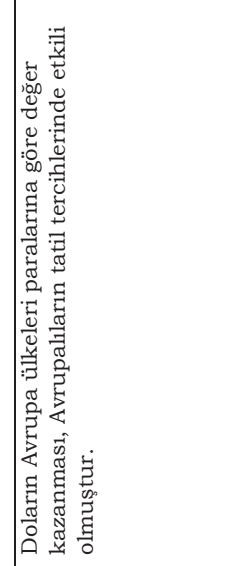 & \\
\hline 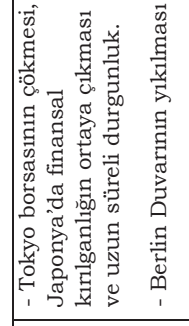 & 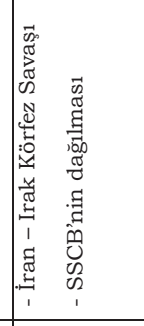 & & 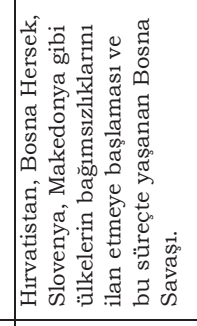 & 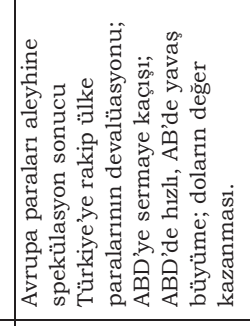 & \\
\hline & $\begin{array}{l}\overrightarrow{\hat{\sigma}} \\
\vec{\sigma}\end{array}$ & & $\begin{array}{l}\delta \\
\delta \\
\sigma\end{array}$ & & 离 \\
\hline
\end{tabular}

Hitit Üniversitesi Sosyal Bilimler Enstitüsü Dergisi - Yıl 10, Sayı 2, Aralık 2017 | 1093 
Sebahattin Emre DİLEK - Nur KULAKOĞLU DİLEK

\begin{tabular}{|c|c|c|c|c|c|c|}
\hline & , & 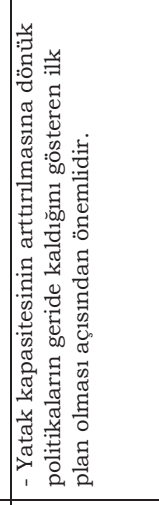 & , & 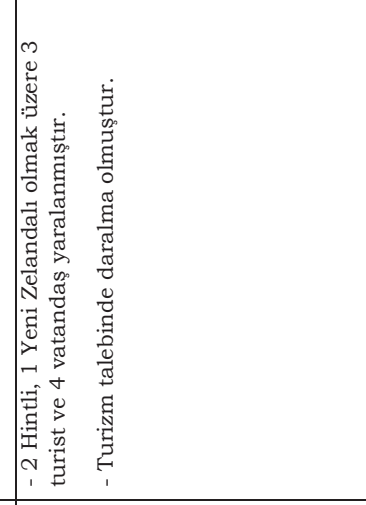 & 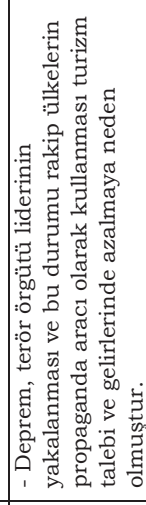 & 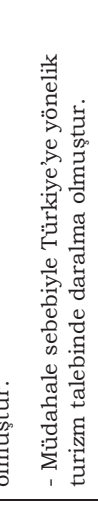 \\
\hline 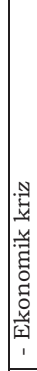 & , & 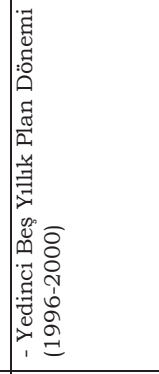 & , & 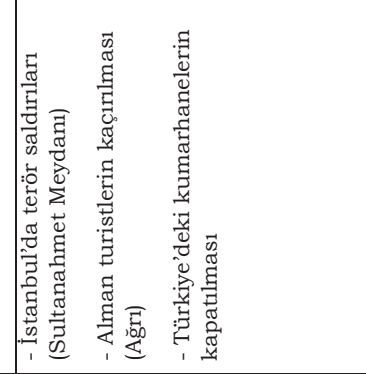 & 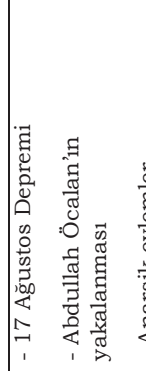 & 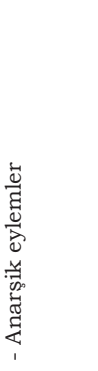 \\
\hline & 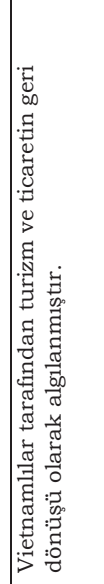 & 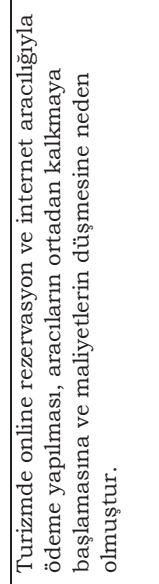 & 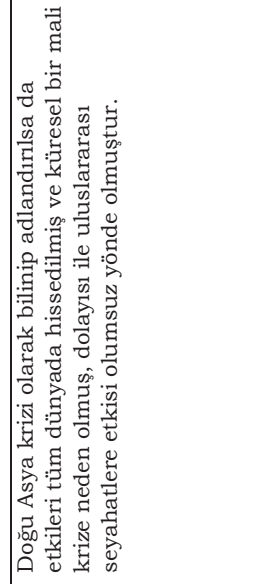 & 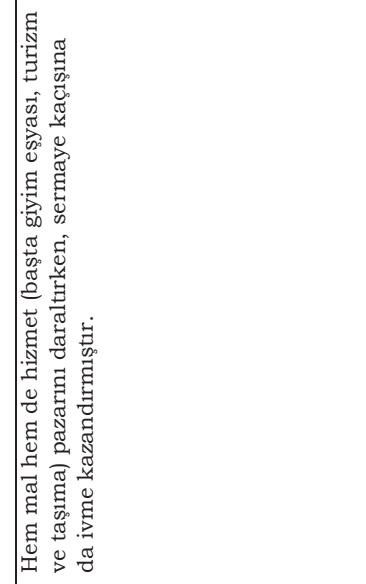 & ' & \\
\hline & 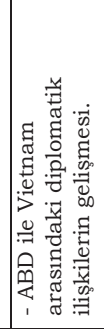 & 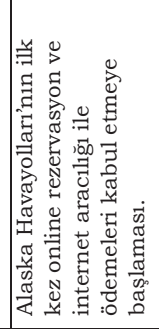 & 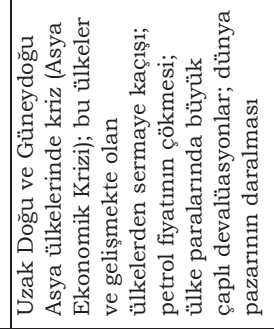 & 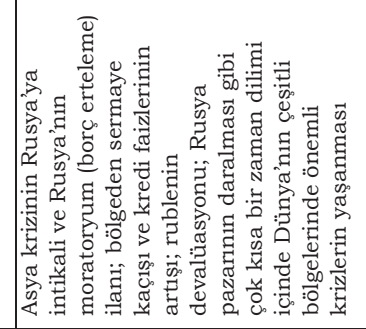 & I & \\
\hline & $\begin{array}{l}\mathscr{2} \\
\Omega \\
\sigma\end{array}$ & 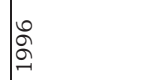 & $\hat{\sigma}$ & 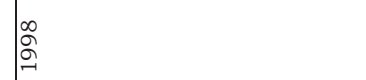 & बे & \\
\hline
\end{tabular}

1094 | Hitit Üniversitesi Sosyal Bilimler Enstitüsü Dergisi - Yıl 10, Sayı 2, Aralık 2017 
Dünyada ve Türkiye’de Yaşanan Olayların Turizme Yansımaları: 1960’tan Günümüze Tarihsel Bir Değerlendirme

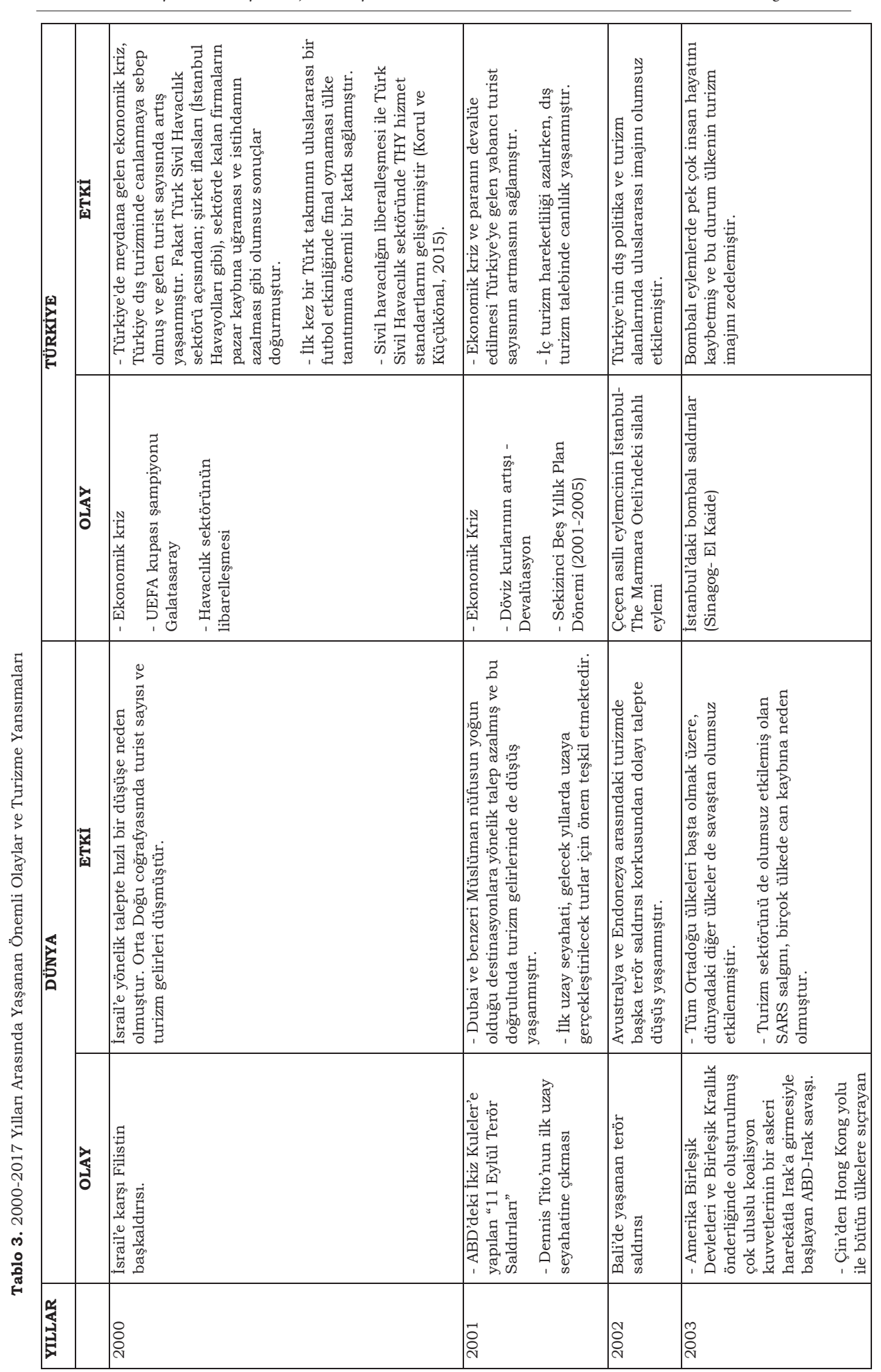

Hitit Üniversitesi Sosyal Bilimler Enstitüsü Dergisi - Yıl 10, Sayı 2, Aralık 2017 | 1095 
Sebahattin Emre DİLEK - Nur KULAKOĞLU DİLEK

\begin{tabular}{|c|c|c|c|c|c|c|c|c|c|}
\hline & 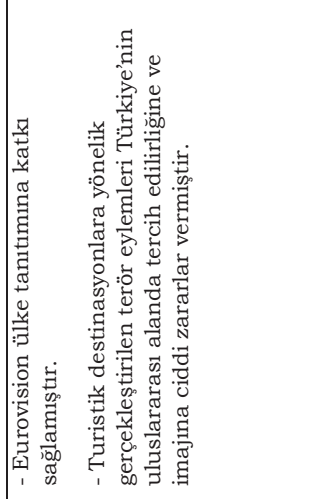 & 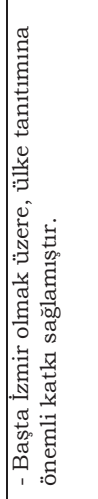 & 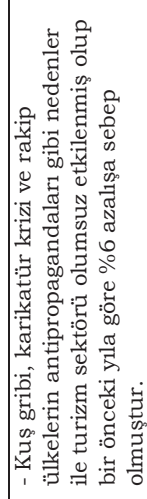 & 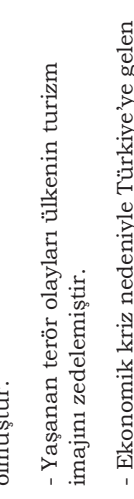 & 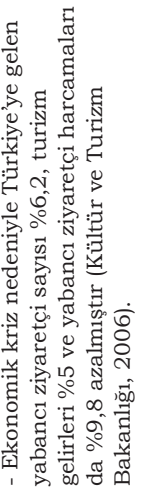 & 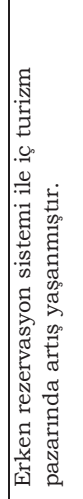 & & 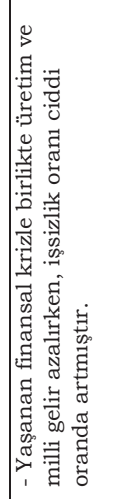 & \\
\hline & 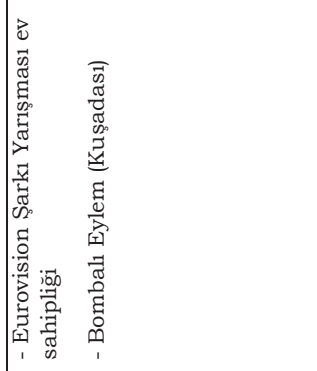 & 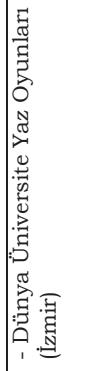 & 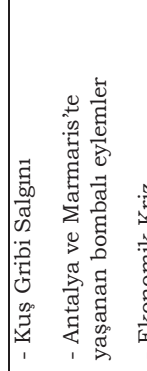 & & & 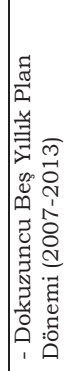 & 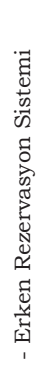 & 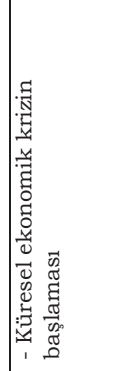 & \\
\hline & 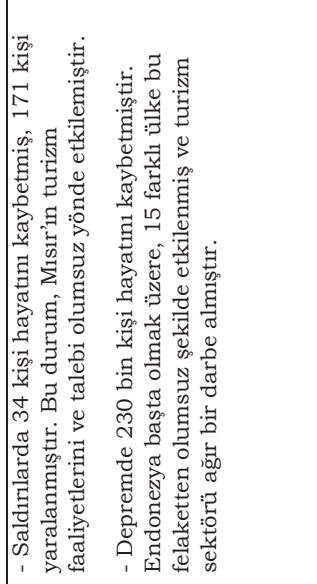 & 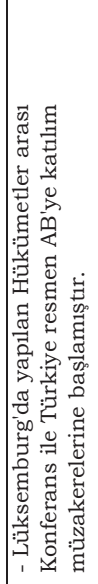 & 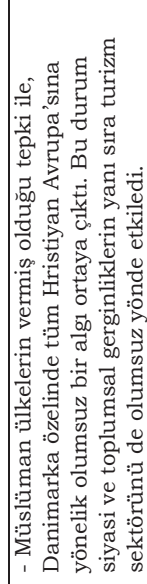 & 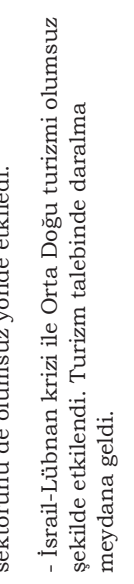 & 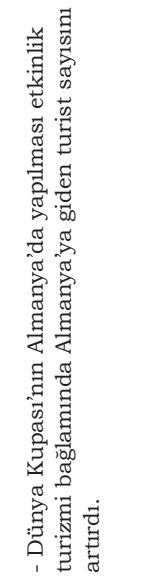 & ' & & 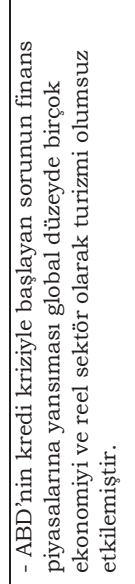 & 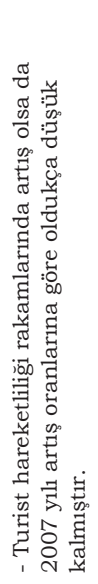 \\
\hline 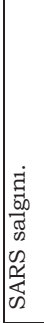 & 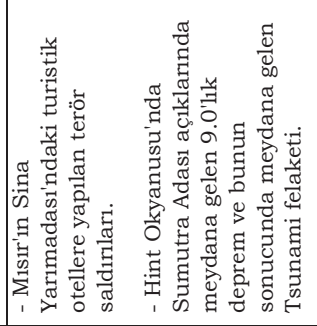 & 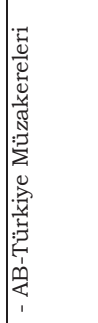 & 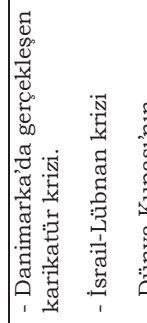 & 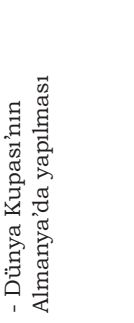 & & ' & & 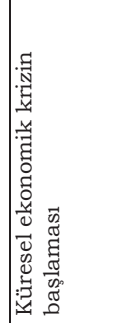 & \\
\hline & 总 & 定 & ஜ & & & 苓 & & 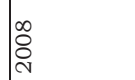 & \\
\hline
\end{tabular}

1096 | Hitit Üniversitesi Sosyal Bilimler Enstitüsü Dergisi - Yıl 10, Sayı 2, Aralık 2017 
Dünyada ve Türkiye’de Yaşanan Olayların Turizme Yansımaları: 1960’tan Günümüze Tarihsel Bir Değerlendirme

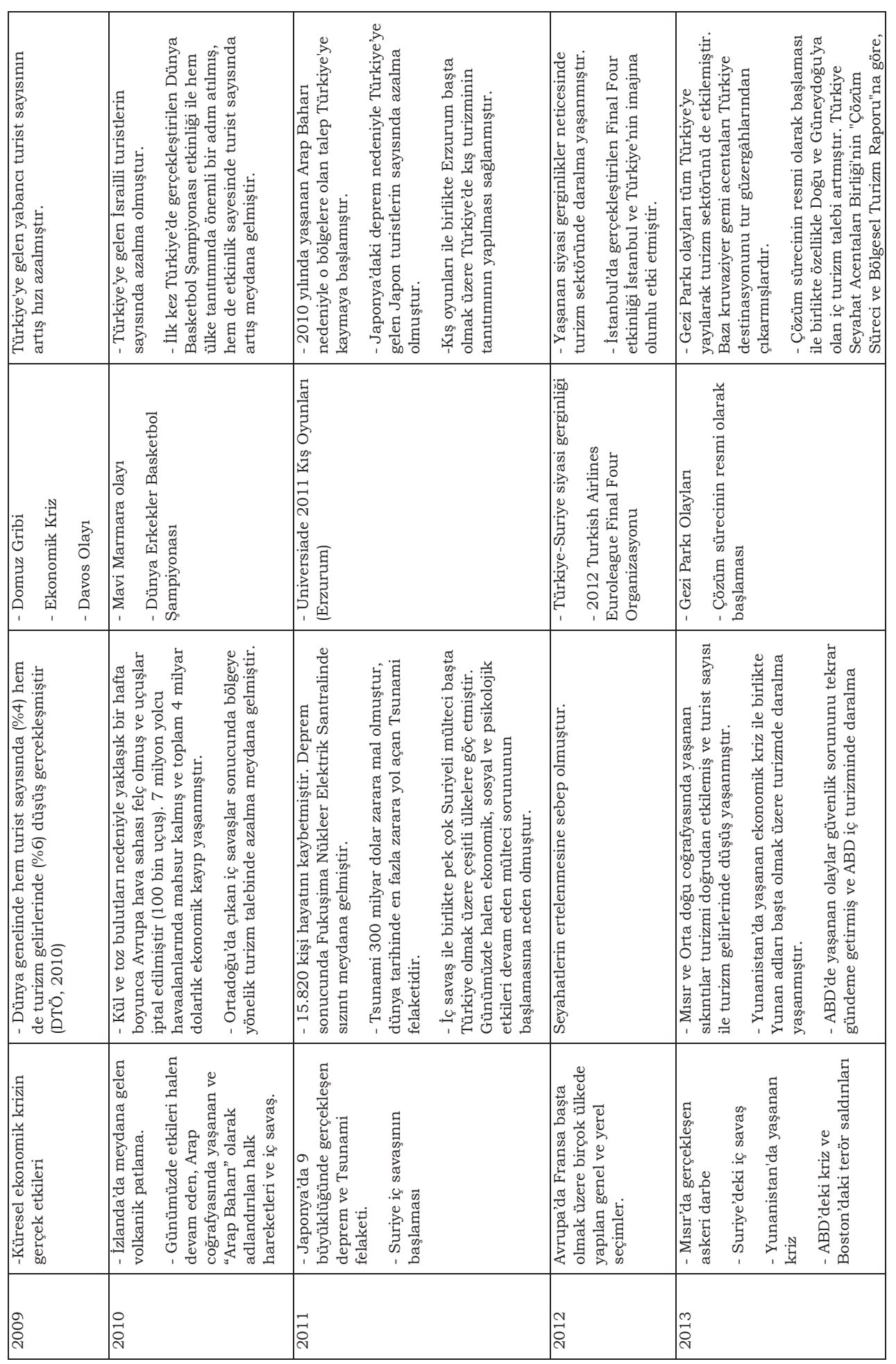

Hitit Üniversitesi Sosyal Bilimler Enstitüsü Dergisi - Yıl 10, Sayı 2, Aralık 2017 | 1097 


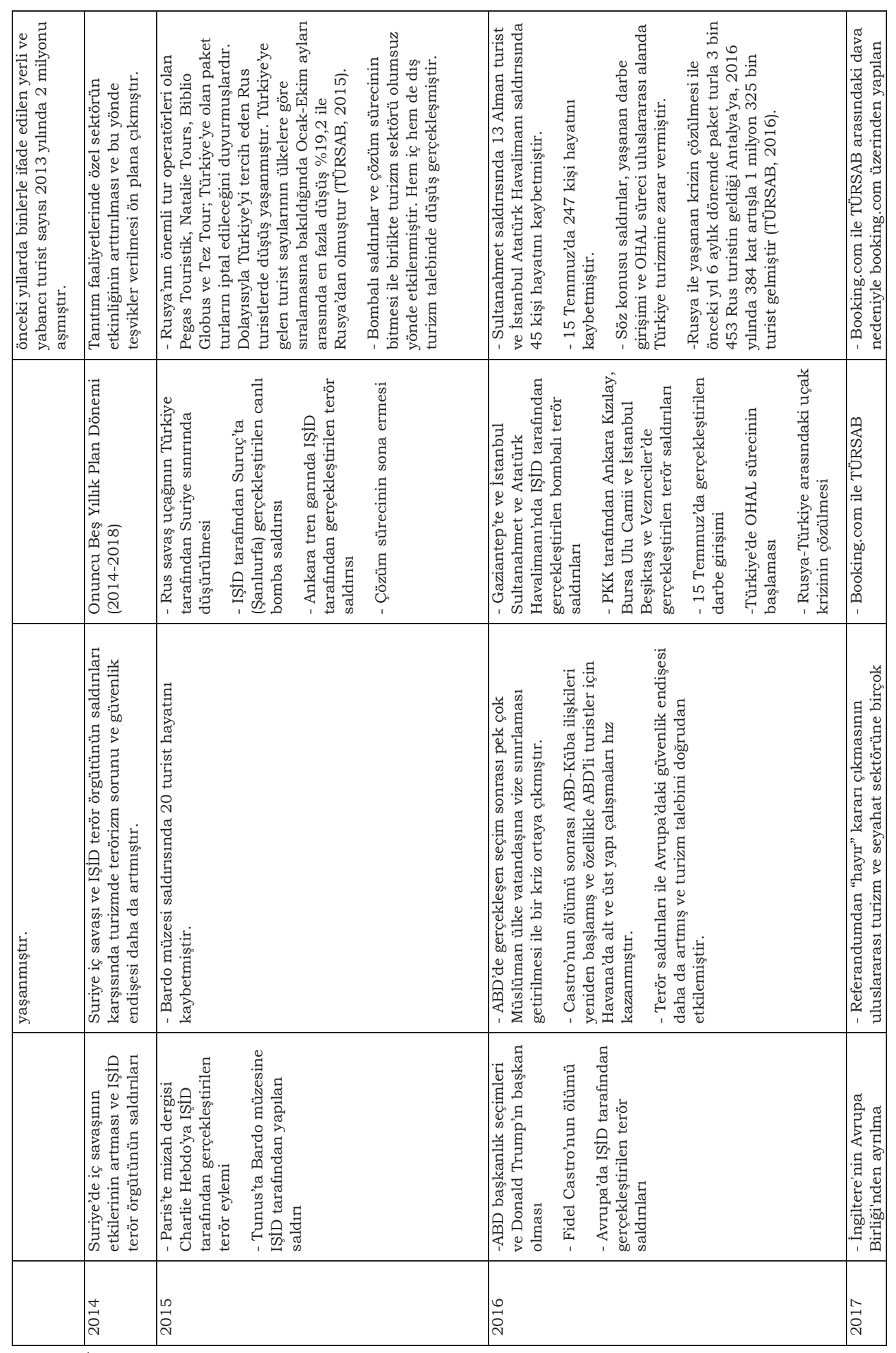

1098 | Hitit Üniversitesi Sosyal Bilimler Enstitüsü Dergisi - Yıl 10, Sayı 2, Aralık 2017 
Dünyada ve Türkiyede Yașanan Olayların Turizme Yansımaları: 1960’tan Günümüze Tarihsel Bir Değerlendirme

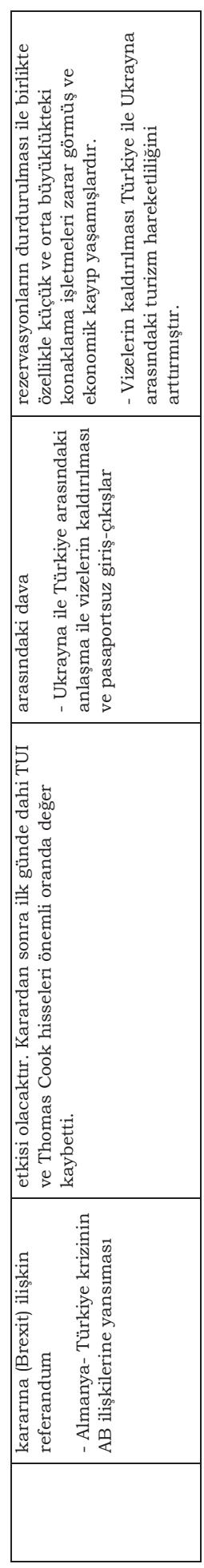




\section{GENEL DEĞERLENDİRME}

\section{A. Yaşanan olayların Dünya turizmine yansımaları}

İkinci Dünya Savaşı'ndan sonra ulaştırma alanında birçok yapısal değişiklik olmaya başlamıştır. Bu değişiklikler sonucu, demir yolu ve deniz yolu taşımacılığ1 önemini kaybederken (Göksan, 1978), özellikle 1960'lardan itibaren devlet kontrolünde olan, yüksek ücret ve zor ulaş1labilirliğe sahip havayolu taşımacılığ büyük ölçüde serbestleşmiş ve oldukça ucuz hale gelmiş, bu da uluslararası kitle turizmine olanak sağlamıştır (Forsyth, 2006). Bunun en önemli sebepleri arasında düşük maliyet prensibine dayalı tarifesiz uçuşlar ile teknolojinin hızlı gelişmesi sayesinde daha uzun menzilli gidebilen hava taşıtlarının havayolu taşımacılığında daha yaygın biçimde kullanılmaya başlaması ve böylelikle sınırların ortadan kalkması sayılabilir. Öyle ki, tarifesiz seferler Avrupa'daki tatil turizminin büyümesini sağlamış ve 1960'lar Avrupa'sında, özellikle İngiltere ve Almanya'dan Güney Avrupa'nın deniz-kum-güneş destinasyonlarına seyahatlerde önemli bir artış yaşanmıştır. Havayollarındaki serbestleşme ile birlikte ülkelerdeki turizm tarzında da büyük değişimler yaşanmıştır. Turist hareketleri kara taşımacılığından hava taşımacılığına geçmiş ve daha uzun yolculuklar yapılmaya başlanmıştır. $\mathrm{Bu}$ durum ülkeler arasındaki destinasyon rekabetçiliğinin de artmasına neden olmuştur (Forsyth, 2006).

1980'li y1llarla birlikte dünyada yaşanan ekonomik krizler ve petrol fiyatlarındaki yükselmeler sebebiyle uluslararası turizm talebinde de bir daralma meydana gelmiştir. Nitekim Dünya Turizm Örgütü verilerine göre yıllar bazında turizm hareketliliği incelendiğinde bu durum açıkça gözlenmektedir. Holloway vd. (2009), bu durumun bir sonucu olan ekonomik düşünme anlayışından dolayı turizm piyasasına, ulaşımdan konaklama ve rehberlik hizmetine kadar pek çok turistik hizmeti bir araya getiren paket turların girmiş olduğunu ifade etmektedir. Başka bir deyişle, 1980'lerin paket turların turizmde yaygınlaşmaya başladığı yıllar olduğu söylenebilmektedir.

1990'lı yıllar ile birlikte özellikle SSCB'nin dağılması ve soğuk savaş döneminin bitmesine paralel olarak uluslararası sermayenin ve yatırımların hız kazanmaya başlaması turizmin de yeni bir ivme kazanmasına neden olmuştur. Nitekim 1980 yılında 278 milyon olan uluslararas1 turist sayıs1, 2000 y1l itibarı ile 674 milyona ulaşmıştır (UNWTO, 2017). 1990'l1 y1llar ayrıca turizm arzının da ivme kazandığı yıllar olarak değerlendirilebilir. Öyle 
ki, oteller, restoranlar, müzeler, alışveriş merkezleri, golf sahaları ve kongre merkezleri gibi birçok yatırım bu dönemde hız kazanmıştır (Purkis 2008'den akt.; Güngör, 2011).

2000'li yıllara gelindiğinde ise, özellikle 2001 yılında ABD'de El Kaide tarafından gerçekleştirilen "11 Eylül Terör Saldırıları" ve yine 2003 yılında ABD'nin Irak'1 işgali sonucunda turizm talebinde önemli dalgalanmalar meydana gelmiştir. İnsanların güvenlik endişesi nedeniyle uzun uçuşları çok fazla tercih etmemesi, özellikle Amerika ve Asya Pasifik ülkelerinde turizm talebinin azalmasına neden olmuştur. 2004 yılında yaşanan Hint Okyanusu depremi ve Tsunami felaketi ise 15 ülkeyi birden etkileyerek turizm sektörüne de ağır bir darbe vurmuştur. Benzer şekilde Sars krizi ve kuş gribi gibi bulaşıcı hastalıklar da uluslararası alanda ülkelerin turizm faaliyetlerini olumsuz yönde etkilemiştir.

2010 yılında başlayan ve Arap Baharı olarak adlandırılan halk hareketleri ve neden olduğu iç savaş, bölgedeki beş ana turistik destinasyona (Mısır, Tunus, Fas, Ürdün ve Lübnan) gelen toplam turist sayısında önemli bir oranda azalma gerçekleşmesine neden olmuştur. Özellikle turizm gelirlerinin söz konusu ülkelerin GSYİH'nın önemli bir bölümünü oluşturduğu göz önüne alındığında, bu düşüş ülkelerin ekonomileri üzerinde son derece olumsuz bir etkiye yol açmıştır (Masetti ve diğerleri, 2013). 2011 yılı itibariyle ortaya çıkan ve günümüze kadar devam eden Suriye iç savaş1, mülteci krizi ve IŞİD terör örgütünün saldırıları ile turizm yine ağır bir darbe almış ve turizmde terörizm sorunu ve güvenlik endişesi birçok ülkenin temel problemlerinden biri haline gelmiştir.

2016 yılında Fidel Castro'nun ölümü sonrası ABD-Küba ilişkilerinin yeniden başlaması ve özellikle ABD'li turistler için Havana'da alt ve üst yap1 çalışmalarının hız kazanması turizm adına olumlu gelişmelerden olsa da, aynı yıl ABD'de gerçekleşen seçim sonrası pek çok Müslüman ülke vatandaşına vize sınırlaması getirilmesi yeni bir krizin ortaya çıkmasına neden olmuştur.

İçinde bulunulan 2017 yılı ise yine dünya turizmini etkileyen ve gelecekte farklı şekillenmesine neden olabilecek olaylara şahitlik etmiştir. Öncelikle İngiltere'nin Avrupa Birliği'nden ayrılma kararına (Brexit) ilişkin referandumdan 'hayır' kararının çıkması ile turizm sektörünün bu durumdan nasıl etkileneceği tartış11ırken, kararın hemen ardından TUI ve Thomas Cook'un borsada yaşadığı önemli değer kaybı, söz konusu endişeleri 
arttıran gelişmeleri çlkarmıştır (https://www.digitallook.com/news/broker-recommendations/thomas-cookand-tui-shares-fall-on-credit-suisse-downgrade--2437662.html).

\section{B. Yaşanan olayların Türkiye turizmine yansımaları}

Planlı dönem öncesinde (1923-1963) turizmle ilgili çalışmalar son derece kısıtlı olmakla birlikte özellikle, planlı kalkınma modelinin benimsendiği 1963 y1lı itibariyle beşer yıllık hazırlanan kalkınma planları ile turizme yönelik çalışmalar da başlamıştır.

1970 ve 1980'li yıllar gerek dünya gerekse Türkiye turizmi açısından hareketli yıllar olmuştur. 1973 yılında yaşanan Arap-İsrail savaş1, 1974'deki Kıbrıs Barış Hareketi, 1980 Askeri Darbesi, Ekonomik Krizler ve yaşanan savaşlar neticesinde ortaya çıkan petrol krizleri söz konusu hareketliliğin başlıca nedenleri olarak sayılabilir. Ancak turizm, Türkiye'nin ekonomik hayatında özellikle 1980'li yıllara kadar çok fazla yer bulamamıştır. Türk turizminin gelişimini hızlandıran unsurlardan biri, 1980'lerden günümüze uluslararası turizmi teşvik eden yasal düzenlemelerin yapılması ve bunun sayesinde yerli ve yabancı turistik yatırımların hızla artmasıdır (Gülbahar, 2009:94). 1982 yılında çıkan Turizm Teşvik Kanunu ve Askeri Darbe sonucu Özal dönemi ile birlikte serbest piyasa ekonomisine geçiş, Türkiye turizmini canlandıran esas gelişim nedenleri olarak gösterilebilmektedir (Duman ve Kozak, 2010).

1990'11 y1llar ise Türkiye turizmi için dönüşüm yılları olarak ifade edilebilir. Nitekim 1991 Irak-İran Körfez Savaşı ile diş talepte yaşanan daralmaya bağlı olarak iç turizme doğru bir eğilim yaşanmıştır. Ayrıca "her şey dâhil sistemi" ve "düşük fiyatlı (low-cost) hava yolu taşımacılığı" nın yaygınlaşması da yine bu yıllara denk gelmektedir. Söz konusu olumlu unsurların yanı sıra 1990'11 yıllarda yaşanan terör saldırıları ise Türkiye turizminde talep daralmasına yol açmıştır (Göçen vd., 2011).

2000'li yıllarda Türkiye'nin turizm endüstrisinde artık turist sayısı ve özellikle turizm geliri sıralamasında ilk on ülke arasında yerini aldığı görülmektedir. Bu dönemde ayrıca turizm yatırımlarına ve dış tanıtıma verilen önem sayesinde Türk turizm sektöründe önemli gelişmeler kaydedilmiş ve dünya turizm endüstrisinden alınan pay büyümüştür (DPT, 2007). Bu büyümeye havac1lık sektörünün liberalleşmesi de önemli katk1 sağlamıştır (Türkiye Turizm Sektörü Raporu, 2010). Yine 2000'li yılların 
başında yaşanan krizler (Türkiye'de yaşanan Türk parasının devalüe olması ve yine aynı yıl ABD'de gerçekleştirilen terörist saldırılar) hem Türkiye hem de dünya turizmi adına farklı gelişmeleri meydana getirmiştir. Türk parasının değer kaybetmesi ile birlikte Türkiye'deki dış turizm talebi yaklaşık olarak 4 milyon kişi artarak 13.4 milyon kişiye ulaşmıştır. Başka bir ifade ile ABD'de terörist saldırıları neticesinde dünya turizm hareketliliğinde bir daralma yaşanırken, Türkiye bundan çok fazla etkilenmemiştir.

Türkiye'ye yönelik turizm talebini etkileyen olaylar açısından bir değerlendirme yapıldığında; 2001 ve 2009 yıllarında yaşanan ekonomik krizler, 2002, 2006 ve 2009 yıllarında görülen salgın hastalıklar (Kırım Kongo Kanamalı Ateşi, kuş gribi, domuz gribi), 2003-2006 y1lları arasında İstanbul, Kuşadas1, Antalya ve Marmaris gibi destinasyonlarda yaşanan terör saldırıları bu dönemde Türk turizmine damgasını vuran olaylar olarak göze çarpmaktadır. Fakat 2001 yılında Türkiye'de meydana gelen ekonomik kriz sonucunda döviz kurlarındaki artış Türk parasının devalüe olmasına neden olmuş ve dolayısıyla turizm talebinde büyüme yaşanmıştır. Bunun yanı sıra 2007 yılında Türkiye'de ilk kez uygulamaya konulan erken rezervasyon sistemi ile beraber iç turizm pazarında da canlanma yaşandığı söylenebilmektedir. 2010 y1lı ise hem Türkiye hem de dünya için önemli bir sürecin başlangıcını oluşturmuştur. Nitekim o yıl gerçekleşen ve etkisi hala devam eden "Arap Baharı", Ortadoğu ülkelerine olan talebin Türkiye ve diğer ülkelere kaymasına neden olmuştur. Arap Baharı nedeniyle 2011 yılında özellikle Mısır ve diğer yakın destinasyonlardan kaçınan turistlerden Türkiye'ye yönelik yaşanan talep kaymas1, 2012'ye gelindiğinde gerilimin sakinleşmesi ile normal seyrine dönmüştür (TÜROFED, 2013).

2012 yılında Türkiye-Suriye arasında yaşanan politik gerginlikler Türkiye turizmi açısından talepteki artış hızının yavaşladığı bir dönem olmuştur. Türkiye'ye en fazla turist gönderen ülkeler arasında onuncu sirada yer alan Suriye'nin özellikle son yıllarda yaşanan olayların da etkisi ile dalgalanmalar yaşadığı ancak 2012'de \% 2,3'lük bir paya sahip olduğu bilinmektedir (Gülbahar, 2009; Kültür ve Turizm Bakanlığı, 2013; Tanıtma Genel Müdürlüğü, 2013; TUİK, 2013).

Bir ülkenin turizmini etkileyen faktörlerin önemli bir kısmını toplumsal olaylar şekillendirmektedir. Nitekim 2013 yılında yaşanan Gezi Parkı olayları tüm Türkiye'ye yayılarak turizm sektörünü de etkilemiştir. Bu süreçte İstanbul'a yönelik talepte başka ülkelere bir kayma yaşanmış olsa da 
uluslararası etkinliklere ev sahipliği yapma, erken rezervasyon sistemleri ve benzeri olaylarla beraber ülke turizmine olan talepte yine de bir artış yaşanmıştır. Aynı yıl 'Çözüm Süreci’nin resmi olarak başlaması ile birlikte turizmde güvenlik problemi ortadan kalkmış ve özellikle Güneydoğu’ya olan iç turizm talebi artmıştır (TÜRSAB, 2014).

2015 y1lında sona eren Çözüm Süreci'yle yeniden güvenlik endişelerinin başlaması hem iç hem de diş turizm talebinde düşüş gerçekleştirmekle birlikte, aynı yıl Rus savaş uçağının Türkiye tarafından düşürülmesiyle yeni bir kriz daha ortaya çıkararak, Türkiye'yi tercih eden Rus turistlerde azalmaya neden olmuştur. 2014 y1lından günümüze IŞİD terör örgütünün saldırılarını Türkiye ve Dünya'nın birçok önemli noktasında gerçekleştirmesi, turizmde terörizm ve güvenlik sorununu en yüksek noktaya çıkarmıştır. 15 Temmuz 2016 tarihi ise Türkiye için oldukça önemli bir diğer dönüm noktasını oluşturmuştur. Darbe girişimi ve akabindeki OHAL süreci uluslararası alanda Türkiye imajına ve Türkiye turizmine ciddi zararlar vermiştir.

İçinde bulunduğumuz 2017 yılında ise, Booking.com ile TÜRSAB arasındaki dava nedeniyle booking.com üzerinden yapılan rezervasyonların durdurulmas1, özellikle küçük ve orta büyüklükteki konaklama işletmelerini zarara uğratmış ve ekonomik kayıpların yaşanmasına neden olmuştur. Olumlu olarak ise, Türkiye ile Ukrayna arasında vizelerin karş11ıklı olarak kaldırılması iki ülke arasındaki turizm hareketliliğini arttırarak sektöre ve ekonomiye nefes aldıran gelişmelerden olmuştur.

\section{SONUÇ VE TARTIŞMA}

Turizm faaliyetleri ülkeler için önemli bir ekonomik olay olmasının yanı sıra, barış ortamının inşasına ve ülkelerarası iletişimin sağlanmasına da katkıda bulunmaktadır. Fakat bu etkileşim içerisinde hem ülke içinde hem de diğer ülkelerde meydana gelen çoğu olaydan da etkilenmektedir. Dolayısıyla turizm; savaş, terör, ekonomik, çevresel, sosyal ve politik krizlere karş1 oldukça hassas bir yapıya sahiptir (Hall ve O’Sulivan, 1996; Fielding ve Shortland, 2011; Hacığlu ve Saylan, 2014).

Dünyada turizm sektöründe izlenen hızlı büyüme eğilimi, Türkiye'de özellikle 1980'li yıllardan itibaren kendini göstermektedir. 1980 sonrası dönemde turizm, ekonomik gelişme için itici bir güç olarak kabul edilmiş ve bu amaçla yetersiz ekonomik kaynakların önemli bir bölümü turizmin gelişimine 
ayrılmıştır. Bu çabalar sonucunda hızlı bir gelişme göstererek Türkiye'nin en genç ve dinamik sektörlerinden biri haline gelen turizm sektörü, günümüzde Türkiye ekonomisinde bir lokomotif rolü oynamaktadır. (Unur, 2002). Genel olarak değerlendirildiğinde, 1963 yılında yaklaşık 200 bin kişiyi ağırlayan Türkiye, günümüzde yaklaşık 40 milyon kişinin ziyaret ettiği önemli bir ülke haline gelmiştir (UNWTO, 2017). Türkiye'ye yönelik talep yıllar itibari ile dalgalı fakat devamlı bir gelişme göstermiştir. Yaşanan olumsuz gelişmeler genellikle uzun dönemleri kapsamasa da, etkileri ve normalleşme süreci çok daha uzun zaman almaktadır (Öztürk ve Şimşek, 2013). Bu nedenle turizmin bir ülkede uzun süre varlığını devam ettirebilmesi o ülkenin iç - dış güvenliği ve siyasi ve ekonomik istikrarının devamına bağlıdır.

Turistik hareketlerin yönünü belirleyen gelişmeleri yalnızca siyasi ya da ekonomik olaylar değil, toplumsal, çevresel ve teknolojik değişimler de etkilemektedir. İçinde bulunduğumuz çağda turizm her geçen gün hıla değişen, kendini yenileyen, değişen şartlara uyum sağlayabilme yeteneği olan ve tüm dünyada sürekli gelişme gösteren bir sektör olarak bilinmektedir. Özellikle 2000'li yıllarla birlikte teknolojide yaşanan önemli değişimler dünya turizminin çehresini değiştirmiş (Şenol ve Turdumanbetov, 2014) ve ülkelerin de uyguladıkları turizm faaliyetlerinde ve planlamalarında teknolojiyi etkin kullanmalarına neden olmuştur. Dolayısıyla turizmden faydalanan ve faydalanmak isteyen ülkeler açısından iç-dış barış ve güven ortam1, komşu coğrafya ülkeleri ile ilişkiler, içsel veya bölgesel siyasi istikrarsızlıklar, ekonomik, toplumsal ve kültürel olaylar, doğa-çevre-iklim sorunları, turist davranışları ve teknolojik değişimler turizm sektörünün belirleyici ve yönlendirici parametreleri olarak yer almaktadır.

\section{KAYNAKÇA}

AÇIKALIN, M., ve KILIÇ, H. (2017), "The Role of Turkish National Holidays in Promoting Character and Citizenship Education", JSSE-Journal of Social Science Education, cilt.16, S.3, ss. 74-83.

BAŞ, T. ve AKTURAN, U. (2008), Nitel Araştırma Yöntemleri: Nvivo 7.0 İle Nitel Veri Analizi. Ankara: Seçkin Yayıncıllk.

BERG, Bruce L. (2012), Qualitative Research Methods for the Social Science (8th Edition). Long Beach, Allyn and Bacon.

BOWEN, G. A. (2005), "Preparing a Qualitative Research-Based Dissertation: Lessons Learned", The Qualitative Report, cilt.10, S.2, ss. 208-222.

BOWEN, G. A. (2009), "Document Analysis as a Qualitative Research Method", Qualitative Research Journal, cilt.9, S. 2, ss. 27-40.

BÜYÜKŞALVARCI, A., ŞAPCILAR, M. C. ve BAYRAKÇI, S. (2016), "Kalkınma Planları Kapsamında Turizm Endüstrisinin Değerlendirilmesi", Selçuk Üniversitesi Sosyal ve Teknik Araştırmalar Dergisi, cilt.11, ss. 186-201. 
DUMAN, T. ve KOZAK, M. (2010), "The Turkish Tourism Product: Differentiation and Competitiveness", Anatolia, cilt.21, S.1, ss. 89-106.

FIELDING, D. ve SHORTLAND, A. (2011), "How Do Tourists React To Political Violence? An Empirical Analaysis Of Tourism In Egypt", Defence And Peace Economics, cilt.22, S.2, ss. 217-243.

FORSYTH, P. (2006), "Aviation and Tourism". L. Dwyer ve P. Forsyth (Ed.). International Handbook on the Economics of Tourism, (ss. 224-245). UK: Edward Elgar Publishing.

GM Turizm Yönetimi Dergisi (2013), “Gezi parkı olayları turizmi nasıl etkiledi?”, (erişim adresi: http://gmdergi.com/online/?p=10236), (erişim tarihi: 28 Ağustos 2017).

GÖÇEN, S., YİRİK, Ş. ve YILMAZ, Y. (2011), “Türkiye'de Krizler ve Krizlerin Turizm Sektörüne Etkileri”, Süleyman Demirel Üniversitesi İktisadi ve İdari Bilimler Fakültesi Dergisi, cilt.16, S.2, ss. 493-502.

GÖKSAN, E. (1978), Turizmoloji. İzmir: Uğur Ofset Matbaası.

GÜLBAHAR, O. (2009), “2000'li yillarda Türkiye'ye Gelen Yabanc1 Ziyaretçi Profili”, Cumhuriyet Üniversitesi İktisadi ve İdari Bilimler Dergisi, cilt.10, S.2, ss. 93112.

GÜNGÖR, A. (2011), "Uluslararası Turizmde Ekonomik Çevre”. İge Pırnar (Ed.), Uluslararası Turizm İşletmeciliği, (ss. 3-18). Ankara: Nobel Yayıncılık.

HACIOĞLU, N. ve SAYLAN, U. (2014), “Arap Baharı'nın Turizme Yansımaları: Arap Ülkeleri ve Türkiye”, Balıkesir Üniversitesi Sosyal Bilimler Enstitüsü Dergisi, cilt.17, S.32, ss. 55-80.

HALL, C. M. ve O'SULLIVAN, V. (1996), “Tourism, Political Instability and Violence”. A. Pizam ve Y. Mansfeld (Ed.). Tourism, Crime and International Security Issues, (ss. 105-120). Newyork: John Wiley.

HOLLOWAY, J. C., HUMPHREYS, C. ve DAVIDSON, R. (2009), The Business of Tourism. Essex: Pearson Education Limited.

KİRİCI, F. (2017), AKP's National EV Project: Only an Election Promise? Turkey's History with National Technology Development and AKP's 2023 Vision, University of Oslo Department of Culture Studies and Oriental Languages Yayımlanmamış Yüksek Lisans Tezi, Norway.

KOFFKA, K. (1999), Principles of Gestalt Psychology (S.44). Routledge, Abingdon, OX.

MASETTİ, O., KÖRNER, K., FORSTER, M. ve FRIEDMAN, J. (2013), "Two Years of Arab Spring: Where Are We Now? What's Next?", Deutsche Bank Research, Germany.

MILES, M. B. ve HUBERMAN, A. M. (1984), Qualitative Data Analysis: A Source Book of New Methods. London: SAGE Publications.

MILES, M. B., ve HUBERMAN, A. M. (1994), Qualitative Sata Analysis: An Expanded Sourcebook. London: SAGE Publications.

OLALI, H. (1963), Turizm Teorisi ve Politikası. İzmir: İzmir Ticaret Odası Yayınlar1 71.

OLALI, H. ve TIMUR, A. (1988), Turizm Ekonomisi. İzmir: Ofis Ticaret Matbaac1lı.

ÖZTÜRK, Y. ve ŞIMSSEK, E. (2013), "Politik İstikrarsılılkların Turistlerin Destinasyon Seçimine Etkisi Üzerine Bir Araştırma", Journal of Tourism and Gastronomy Studies, cilt.1, S.2, ss. 15-25.

SOLSO, R. L. (1991), Cognitive Psychology (3rd Edision). Boston: Allyn and Bacon.

ŞENOL, F. ve TURDUMANBETOV, B. (2014). "Toplumsal Olaylar ve Ülke Turizmi Üzerindeki Muhtemel Etkileri: Kırgızistan Örneği”, Kastamonu Üniversitesi İktisadi ve İdari Bilimler Fakültesi Dergisi, cilt.4, S.2, ss. 96-110.

T.C. BASSBAKANLIK YATIRIM DESTEK VE TANITIM AJANSI. (2010), "Türkiye Turizm Sektörü Raporu", (erişim adresi: $\quad$ http://www.invest.gov.tr/trTR/infocenter/publications/Documents/TURIZM.SEKTORU.pdf), (erişim tarihi: 05 Eylül 2017).

T.C. KALKINMA BAKANLIĞI. (1963), “T.C. Başbakanlık, Devlet Planlama Teşkilatı Müsteşarlığı, Birinci Beş Yıllık Kalkınma Planı", (erişim adresi: http://www.kalkinma.gov.tr/Lists/Kalknma\%20Planlar/Attachments/9/plan1. pdf), (erişim tarihi: 05 Eylül 2017). 
T.C. KALKINMA BAKANLIĞI. (1968), “T.C. Başbakanlık, Devlet Planlama Teşkilatı Müsteşarlığı, İkinci Beş Yıllık Kalkınma Planı", (erişim adresi: http://www.kalkinma.gov.tr/Lists/Kalknma\%20Planlar/Attachments/8/plan2. pdf), (erişim tarihi: 05 Eylül 2017).

T.C. KALKINMA BAKANLIĞI. (1973), "T.C. Başbakanlık, Devlet Planlama Teşkilatı Müsteşarlığı, Üçüncü Beş Yıllık Kalkınma Planı", (erişim adresi: http://www.kalkinma.gov.tr/Lists/Kalknma\%20Planlar/Attachments/7/plan3. pdf), (erișim tarihi: 05 Eylül 2017).

T.C. KALKINMA BAKANLIĞI. (1979), "T.C. Başbakanlık, Devlet Planlama Teşkilatı Müsteşarlığı, Dördüncü Beş Yıllık Kalkınma Planı", (erişim adresi: http://www.kalkinma.gov.tr/Lists/Kalknma\%20Planlar/Attachments/6/plan4. pdff), (erişim tarihi: 05 Eylül 2017).

T.C. KALKINMA BAKANLIĞI. (1985), "T.C. Başbakanlık, Devlet Planlama Teşkilatı Müsteşarlığı, Beşinci Beş Yıllık Kalkınma Planı", (erişim adresi: http://www.kalkinma.gov.tr/Lists/Kalknma\%20Planlar/Attachments/5/plan5. pdff), (erişim tarihi: 05 Eylül 2017).

T.C. KALKINMA BAKANLIĞI. (1990), "T.C. Başbakanlık, Devlet Planlama Teşkilatı Müsteşarlığı, Altıncı Beş Yıllık Kalkınma Planı", (erişim adresi: http://www.kalkinma.gov.tr/Lists/Kalknma\%20Planlar/Attachments/4/plan6. $p d f$ ), (erişim tarihi: 05 Eylül 2017).

T.C. KALKINMA BAKANLIĞI. (1996), "T.C. Başbakanlık, Devlet Planlama Teşkilatı Müsteşarlığı, Yedinci Beş Yıllı Kalkınma Planı", (erişim adresi: http://www.kalkinma.gov.tr/Lists/Kalknma\%20Planlar/Attachments/3/plan7. pdff), (erişim tarihi: 05 Eylül 2017).

T.C. KALKINMA BAKANLIĞI. (2001), "T.C. Başbakanlık, Devlet Planlama Teşkilatı Müsteşarlığı, Sekizinci Beş Y1llık Kalkınma Planı", (erişim adresi: http://www.kalkinma.gov.tr/Lists/Kalknma\%20Planlar/Attachments/2/plan8. pdff), (erişim tarihi: 05 Eylül 2017).

T.C. KALKINMA BAKANLIĞI. (2007), "T.C. Başbakanlık, Devlet Planlama Teşkilatı Müsteşarlığı, Dokuzuncu Beş Yıllık Kalkınma Planı”, (erişim adresi: http://www.kalkinma.gov.tr/Lists/Kalknma\%20Planlar/Attachments/1/plan9. pdf), (erişim tarihi: 05 Eylül 2017).

T.C. KALKINMA BAKANLIĞI. (2014), "T.C. Başbakanlık, Devlet Planlama Teşkilatı Müsteşarlığı, Onuncu Beş Yıllık Kalkınma Planı", (erişim adresi: http:// www.kalkinma.gov.tr/Lists/Kalknma\%20Planlar/Attachments/12/Onun cu\%20Kalk\%C4\%B1nma\%20Plan\%C4\%B1.pdf), (erişim tarihi: 05 Eylül 2017).

T.C. KÜLTÜR VE TURIZM BAKANLIĞI. (2013), (erişim adresi: http://www.tanitma.gov.tr/Eklenti/4793, bilgilendirme-raporu.pdf?O), (erişim tarihi: 10 Temmuz 2017).

T.C. KÜLTÜR VE TURIZZM BAKANLIĞI YATIRIM VE İŞLETMELER GENEL MÜDÜRLÜĞÜ. (2006), "2006 Yılı Sınır Giriş- Çıkış İstatistikleri”, (erişim adresi: http://yigm.kulturturizm.gov.tr/TR,9854/sinir-giris-cikis-istatistikleri.html), (erişim tarihi: 13 Kasım 2017

TANITMA GENEL MÜDÜRLÜĞÜ. (2013), “2012 Pazar Raporları”, (erişim adresi: http://www.tanitma.gov.tr/TR,22435/2012-yili-pazar-raporlari.html), (erişim tarihi: 05 Eylül 2017

Tarihte Bugün. (2017), "Yıllar bazında tarihsel olaylar", (erişim adresi: http://www.tarihtebugun.org/tarihte_yil_sene.html), (erissim tarihi: 21 Ağustos 2017).

TUIKK. (2013), “2013 Turizm İstatistikleri”, (erişim adresi: www.tuik.gov.tr/IcerikGetir.do?istab_id=69), (erişim tarihi: 05 Eylül 2017).

TÜRSAB. (2016), "2016 Turizm Verileri”, (erişim adresi: https://www.tursab.org.tr/tr/turizm-verileri/istatistikler), (erişim tarihi: 03 Eylül 2017). 
TÜRSAB. (2015), "Incoming Turizm Raporu", (erişim adresi: http://www.tursab.org.tr/dosya/ 13586/ekim2015_13586_5149287.pdf), (erişim tarihi: 03 Eylül 2017).

TÜRSAB. (2014), "Çözüm Süreci ve Bölgesel Turizm Raporu”, (erişim adresi: https://www.tursab.org.tr/dosya/11581/tursab-cozum-sureci-ve-bolgeselturizm-raporu_11581_3785472.pdf), (erissim tarihi: 03 Eylül 2017).

UNUR, K. (2002), Türkiye'nin Ekonomik Etkilerinin Ölçmede Kullantlan Yöntemler ve Türkiye'nin Aktif Diş Turizm Gelirlerinin Ölçmede Kullanilan Yöntemlerin Ölçümü İçin Bir Model Önerisi, Dokuz Eylül Üniversitesi Sosyal Bilimler Enstitüsü Yayımlanmamış Doktora Tezi, İzmir.

UNWTO (Dünya Turizm Örgütü). (2017), Tourism Highlights, 2017 Edition. Madrid: UNWTO.

UNWTO (Dünya Turizm Örgütü). (2010), Annual Report, 2010 Edition. Madrid: UNWTO.

YILDIRIM, A. ve ŞİMŞEK, H. (2008), Sosyal Bilimlerde Nitel Araştırma Yöntemleri, Ankara: Seçkin Yayıncılık.

WALCOTT, H. F. (1994), Transforming Qualitative Data: Description, Analysis and Interpretation, London: SAGE Publications. 